\title{
Retinoic Acid Receptor-Dependent Survival of Olfactory Sensory Neurons in Postnatal and Adult Mice
}

\author{
Maria Hägglund, ${ }^{1}$ Anna Berghard, ${ }^{1}$ Jörg Strotmann, ${ }^{2}$ and Staffan Bohm ${ }^{1}$ \\ ${ }^{1}$ Department of Molecular Biology, Umeå University, SE901 87 Umeå, Sweden, and 2Institute of Physiology, University of Hohenheim, D-70593 Stuttgart, \\ Germany
}

To address the hypothesis that retinoids produced by synthesizing enzymes present in the primary olfactory system influence the mouse olfactory sensory map, we expressed a dominant-negative retinoic acid receptor selectively in olfactory sensory neurons. We show that neurons deficient in nuclear retinoid signaling are responsive to odors and form correct odorant receptor-specific axonal projections to target neurons in the olfactory bulb of the brain. Subsequent to the formation of the map, the neurons die prematurely by retrogradedriven caspase- 3 activation, which resembles the previously described mechanism of neural death after olfactory bulb ablation. This neurodegenerative event is initiated the second postnatal week and occurs in the adult animal without a compensatory increase of progenitor cell proliferation. In addition, we find that nuclear retinoid signaling is required for the expression of a retinoic acid-degrading enzyme, Cyp26B1, in a small fraction of mature neurons. Collectively, the results provide evidence for a role of locally regulated retinoid metabolism in neuroprotection and in determining population size of neurons at a late stage of neural circuit formation.

Key words: apoptosis; neuron; olfactory; RAR; postnatal; retinoic acid

\section{Introduction}

Localized synthesis and degradation of bioactive vitamin A derivatives (retinoids) mediated by retinal dehydrogenases (RALDHs) and specific cytochrome P450 enzymes (Cyp26s) provide a mechanism for temporal and spatial regulation of retinoid signaling in the nervous system (McCaffery et al., 1999; Thompson Haskell et al., 2002; Reijntjes et al., 2005). Retinoids influence early developmental events such as patterning, neurogenesis, neuronal specification, and axonal outgrowth by binding to nuclear retinoid receptors [retinoic acid receptors (RARs) and retinoid X receptors (RXRs)] that regulate gene transcription (Chambon, 1996; Maden, 2001). Retinoids continue to play a critical role in the mature nervous system, effecting adult neurogenesis, plasticity, and cognitive decline associated with aging (Chiang et al., 1998; Etchamendy et al., 2001; Misner et al., 2001; Thompson Haskell et al., 2002; Crandall et al., 2004; Wang et al., 2005). In addition, defective retinoid signaling has been implicated in neurodegenerative diseases such as Alzheimer's disease and amyotrophic lateral sclerosis (Corcoran et al., 2002, 2004; Goodman and Pardee, 2003).

Olfactory sensory neurons (OSNs) in the olfactory epithelium and their synaptic target structures, the glomeruli of the olfactory

Received Nov. 21, 2005; revised Feb. 7, 2006; accepted Feb. 7, 2006.

This work was supported by Swedish Natural Science Research Council Grant B5101-1250/2001 and Deutsche Forschungsgemeinschaft Sonderforschungsbereich 495. M.H. was supported by a National Network in Neuroscience graduate student fellowship (a Stiftelsen för Strategisk Forskning). We thank Dr. Peter Mombaerts for kindly providing P2-IRES-tauLacZ mice, Dr. Janet Rossant for the RARE-HspLacZ mice, Dr. Frank Margolis for the OMP antibody, and Dr. Martin Gullberg for the Stathmin/SCG10 antibody.

Correspondence should be addressed to Staffan Bohm, Department of Molecular Biology, Umeå University, Umeå, SE901 87 Sweden. E-mail: staffan.bohm@molbiol.umu.se

DOI:10.1523/JNEUROSCI.4955-05.2006

Copyright $\odot 2006$ Society for Neuroscience $\quad$ 0270-6474/06/263281-11\$15.00/0 bulb, provide a useful system to determine the role of retinoid signaling during formation, refinement, maintenance, and/or regeneration of an axonal projection map in mammals. In mice, the olfactory projection map is formed by $\sim 1000$ scattered subpopulations of OSNs, each expressing a specific odorant receptor gene, that project with their axons to topographically defined glomeruli (Ressler et al., 1994; Vassar et al., 1994). Dividing neural progenitor cells, located in the basal cell layer of the olfactory epithelium, replenish the OSNs that degenerate continuously in the adult animal (Graziadei and Graziadei, 1979; Schwob, 2002). Evidence that OSNs respond to retinoids has come from expression studies of RARs, RXRs, and cellular retinoic acid binding protein type I (CRABP-I), as well as from analyses of retinoic acid response element (RARE)-driven $\beta$-galactosidase ( $\beta$ gal) expression in transgenic mice (Whitesides et al., 1998; Gustafson et al., 1999; Krezel et al., 1999; Zetterstrom et al., 1999; Zhang, 1999; Asson-Batres et al., 2003a). The relevance of retinoid signaling not only during the initial morphogenesis of the olfactory epithelium (LaMantia et al., 2000) but also postdevelopmentally is indicated by the presence of RALDH-positive cells in the vicinity of OSN cell bodies and their axons in the olfactory nerve and olfactory bulb (Norlin et al., 2001; Niederreither et al., 2002; Wagner et al., 2002). A study of vitamin A-deficient adult rats has provided a link between retinoid signaling and regulation of cell dynamics in the olfactory epithelium of adult animals (AssonBatres et al., 2003b). However, the pleiotropic effects of vitamin A derivatives have made it difficult to determine whether retinoid signals act directly or indirectly on OSNs and/or their progenitors.

We used the promoter of the olfactory marker protein (OMP) gene (Danciger et al., 1989) to generate transgenic mice with OSNs that express a mutated RAR variant (RAR $\alpha 403)$ that inhib- 
its the function of endogenous RARs. This way, the direct responses of OSNs to retinoids during late stages of olfactory map formation and maintenance may be selectively examined. We provide evidence that RARE-dependent transcription and local homeostatic control of retinoids is required for the maintenance of a population of functional neurons with established projections and that inhibition of retinoid signaling results in postnatal and adult neurodegeneration.

\section{Materials and Methods}

Generation of transgenic mice. The coding sequence of dominantnegative RAR (dnRAR) (hRAR $\alpha 403$ ) (Damm et al., 1993) was ligated 3' to a $6 \mathrm{~kb}$ fragment of the mouse OMP promoter and $5^{\prime}$ to a simian virus 40 (SV40) polyadenylation site (Alenius and Bohm, 2003). A DNA fragment corresponding to the OMP-dnRAR-SV40poly $\left(\mathrm{A}^{+}\right)$transgene was gel purified and microinjected into pronuclei of C57BL/6/CBA one-cell embryos. Four independent founder lines that expressed the dominantnegative RAR construct selectively in OSNs were generated. Transgenic founder mice were backcrossed to C57BL/6J mice (Taconic M \& B, Ry, Denmark), for more than four generations. The progeny from all transgenic founder lines that expressed dnRAR displayed the same morphological phenotype in the olfactory epithelium (data not shown). All animal experiments were approved by the ethical committee at Umeå University.

In situ hybridization. Tissue with olfactory mucosa were dissected from cervical dislocated mice and fixed overnight at $4^{\circ} \mathrm{C}$ in $4 \%$ paraformaldehyde in PBS. Tissues were cryoprotected in $30 \%$ sucrose at $4^{\circ} \mathrm{C}$ for $24 \mathrm{~h}$, frozen in Tissue-Tek O.C.T. (Sakura Finetek, Torrance, CA), and cryosectioned at $12 \mu \mathrm{m}$ and pretreated, hybridized, and washed (Alenius and Bohm, 2003). Sections were hybridized at $52^{\circ} \mathrm{C}$ overnight with ${ }^{35} \mathrm{~S}$ labeled cRNA probes specific to the following: hRAR $\alpha 403$ (1-2914 bp; GenBank accession number X06614), mRAR $\alpha$ [expressed sequence tag (EST) clone; GenBank accession number BF120655], mRAR $\beta 2$ (EST clone; GenBank accession number AA673166), and mRAR $\gamma$ (EST clone; GenBank accession number BI904383). Probes specific to different odorant receptors (M40, K20, and M50) were as described previously (Sullivan et al., 1995). Slides were dehydrated and processed for autoradiography using NTB-emulsion (Eastman Kodak, Rochester, NY) and exposed for $5-14 \mathrm{~d}$ at $4^{\circ} \mathrm{C}$. In situ hybridization using digoxygeninlabeled Cyp26B1 (EST clone; GenBank accession number BQ770766) probe was performed as described previously (Schaeren-Wiemers and Gerfin-Moser, 1993). Hoechst 33258 was used as histological stain, and analysis was performed using both fluorescent and dark-field optics on a Zeiss (Oberkochen, Germany) Axioskop microscope with a Hamamatsu (Shizouka, Japan) digital CCD camera. Images were processed using Adobe Photoshop version 7.0.1 (Adobe Systems, San Jose, CA). Brightness and contrast adjustments of images were done linearly.

Immunohistochemistry and 5-bromo-2'-deoxyuridine labeling. Olfactory mucosa and olfactory bulb tissue were dissected from cervical dislocated mice and fixed in 4\% paraformaldehyde in PBS for 30-90 min at room temperature or overnight for phosphorylated-cAMP response element-binding protein (phospho-CREB) immunohistochemical analyses, cryoprotected in $30 \%$ sucrose at $4^{\circ} \mathrm{C}$ for $24 \mathrm{~h}$, frozen in Tissue-Tek O.C.T., and cryosectioned (12-20 $\mu \mathrm{m})$. Tissue of 4 weeks and older mice was decalcified for 10-20 min in RDO Rapid Decalcifier (Apex Engineering Products, Aurora, IL). c-Fos antigen retrieval was done by heat treatment in $10 \mathrm{~mm}$ citrate buffer, $\mathrm{pH}$ 6.0, for $10 \mathrm{~min}$. Nonspecific background was blocked by incubation for $1 \mathrm{~h}$ in $2 \%$ bovine serum albumin in Tris-buffered saline (TBS) with $0.3 \%$ Triton X-100, followed by overnight incubation at $4^{\circ} \mathrm{C}$ in TBS, $0.3 \%$ Triton $\mathrm{X}-100$ containing antiphospho-histone 3 (H3) (1:500; Upstate Biotechnology, Lake Placid, NY), anti-activated caspase-3 (1:500; BD Biosciences, Mountain View, CA), anti-OMP (1:1000), anti-stathmin/SCG10 (1:1000), anti-tyrosine hydroxylase (TH) (1:500; Pel-Freez Biologicals, Rogers, AR), antiphosphorylated CREB (1:200; Upstate Biotechnology), anti-c-Fos (1:4000; Oncogene Sciences, Uniondale, NY), and anti-OR256-17 [1:1000 (Strotmann et al., 2004)]. Sections were washed with TBS and $0.3 \%$ Triton X-100 and incubated for $1 \mathrm{~h}$ with fluorescently labeled secondary antibodies [cyanine 3-conjugated goat anti-rabbit IgG (Jackson
ImmunoResearch, West Grove, PA) or Alexa Fluor 488-conjugated donkey anti-goat IgG (Invitrogen, Carlsbad, CA)]. Sections were counterstained with Hoechst 33258 (Sigma, St. Louis, MO). Double caspase-3/ OMP images were produced using a Leica (Nussloch, Germany) DM IRB confocal microscope with argon and helium/neon lasers. Caspase-3positive and OMP-positive cells were detected with a $40 \times$ oil-immersion lens using Alexa Fluor 488-conjugated donkey anti-rabbit IgG and Alexa Fluor 546-conjugated donkey anti-goat IgG (Invitrogen), respectively. A total of 60 and 80 caspase-3-positive cells in the neural cell layer of the olfactory epithelium of control and dnRAR transgenic mice, respectively, were identified by optical sectioning, and $1.5 \mu \mathrm{m} Z$ images of positive cells were analyzed sequentially for OMP immunoreactivity. Intraperitoneal injections of $50 \mu \mathrm{g} / \mathrm{g}$ 5-bromo-2'-deoxyuridine (BrdU) (BD Biosciences PharMingen, San Diego, CA) were done three times with an interval of $3 \mathrm{~h}$, and tissues were taken for analysis $24 \mathrm{~h}$ after the last injection. For the BrdU immunohistochemical analysis, an anti-BrdU antibody (1:10; BD Biosciences PharMingen) was used.

Odor exposure. Odor exposure was done according to Norlin et al. (2005). Two-week-old mice were placed in an odor-free $4 \mathrm{dm}^{3}$ plastic box with a tight seal for $20 \mathrm{~min}$, after which an odor was presented by introducing a sealed, perforated container that contained $25 \mu \mathrm{l} / \mathrm{dm}^{3}$ pyridine. After exposure for $10 \mathrm{~min}$, the odor was removed, mice were killed $60 \mathrm{~min}$ after the end of odor exposure, and tissues were processed for immunohistochemistry.

Bgal-histochemical analyses of RARE, P2, and MOL2.3 reporter mice. Transgenic mice were crossed to P2-IRES-tauLacZ mice (Mombaerts et al., 1996), MOL2.3-IRES-tauLacZ-IRES-GFP (Conzelmann et al., 2000), or RARE-Hsp-LacZ mice. Tissues from the F1 generation of these crosses were processed and sectioned at $20 \mu \mathrm{m}$ as described above. Slides were rinsed three times for $20 \mathrm{~min}$ in $0.1 \mathrm{M}$ phosphate buffer, $2 \mathrm{mM} \mathrm{MgCl}, 5$ mM EGTA, $0.02 \%$ Nonidet P-40, and $0.001 \%$ sodium deoxycholate. The staining reaction was performed at $37^{\circ} \mathrm{C}$ overnight in the same buffer, supplemented with $1 \mathrm{mg} / \mathrm{ml}$ 5-bromo-4-chloro-3-indolyl- $\beta$-Dgalactopyranoside, $5 \mathrm{~mm} \mathrm{~K}_{3} \mathrm{Fe}(\mathrm{CN})_{6}$, and $5 \mathrm{~mm} \mathrm{~K}_{4} \mathrm{Fe}(\mathrm{CN})_{6}$. Sections were subsequently rinsed three times in PBS and counterstained with Hoechst 33258.

Quantification of $\beta$ gal, phospho-H3, and activated caspase-3-positive OSNs. The numbers of caspase-3-positive cells and $\beta$ gal-positive cells in P2-IRES-tauLacZ, MOL2.3-IRES-tauLacZ, or RARE-LacZ mice were counted for every sixth (7-month-old mice), every fifth (4- and 6-weekold mice), or every fourth (2-week-old mice), every third (1-week-old mice), and every second (newborn mice) coronal section, throughout the rostrocaudal extent of the nasal cavity, and the numbers obtained were multiplied by six, five, four, three, or two, respectively, to estimate the total number per nasal cavity. The numbers of phospho-H3-positive cells were estimated in the same way, except that the region analyzed was limited to the olfactory epithelium that lined the septum. Numbers of phospho-CREB and c-Fos-positive cells were from a 330- $\mu \mathrm{m}$-long epithelial section lining the septum. The thickness of the epithelium was quantified for each image, and the numbers of positive cells per square micrometer were calculated. The numbers of c-Fos-positive periglomerular cells were counted for a region of the periglomerular layer that spanned 10 glomeruli and that was located in the medial part of the olfactory bulb. Student's $t$ test (two-tailed) was used to determine statistical significance of all datasets.

\section{Results \\ Reduced number of mature OSNs in postnatal OMP-dnRAR mice}

To determine the role of RAR-dependent gene expression in OSNs, we generated transgenic mouse lines that expressed dnRAR under the transcriptional control of a $6 \mathrm{~kb}$ gene regulatory region of the mouse OMP gene that drives OSN-specific transgene expression in both immature and mature OSNs (Fig. 1A) (Alenius and Bohm, 2003). OMP and odorant receptor transcripts are expressed before olfactory axons form synapses with olfactory bulb neurons, and contact with the olfactory bulb is not necessary for their expression (Sullivan et al., 1995). The dnRAR 
A
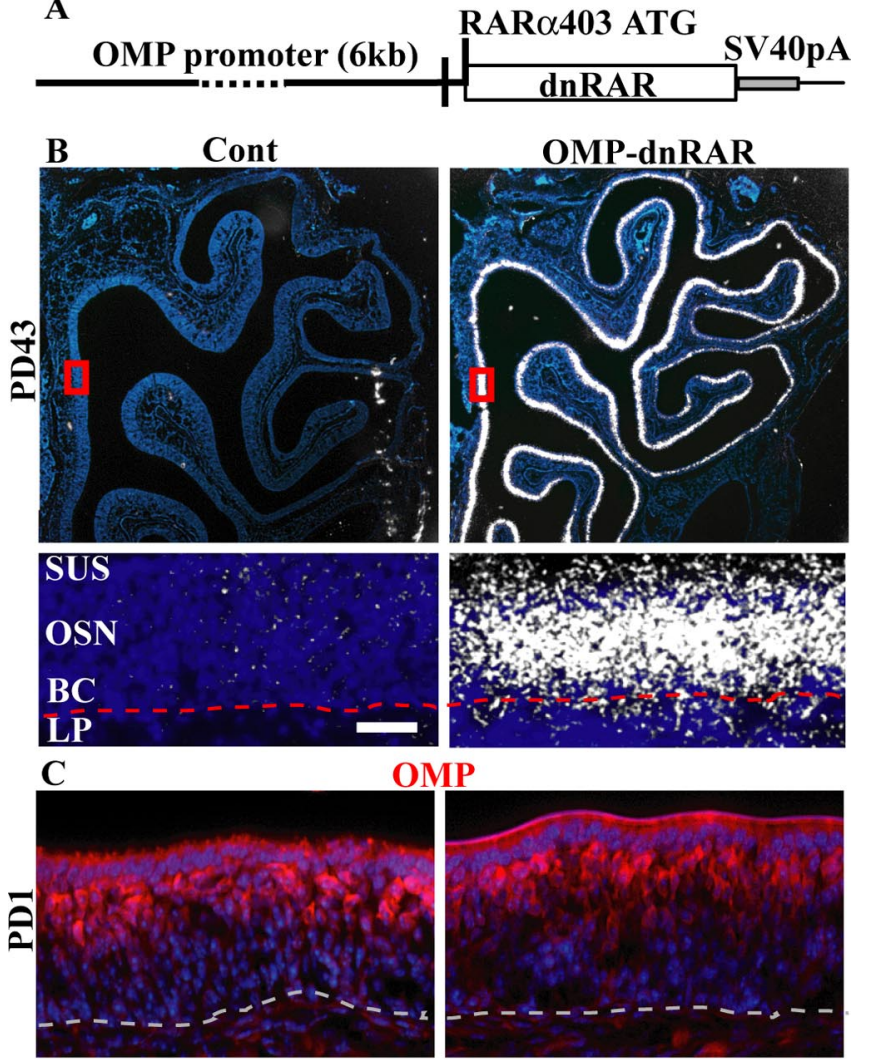

MP
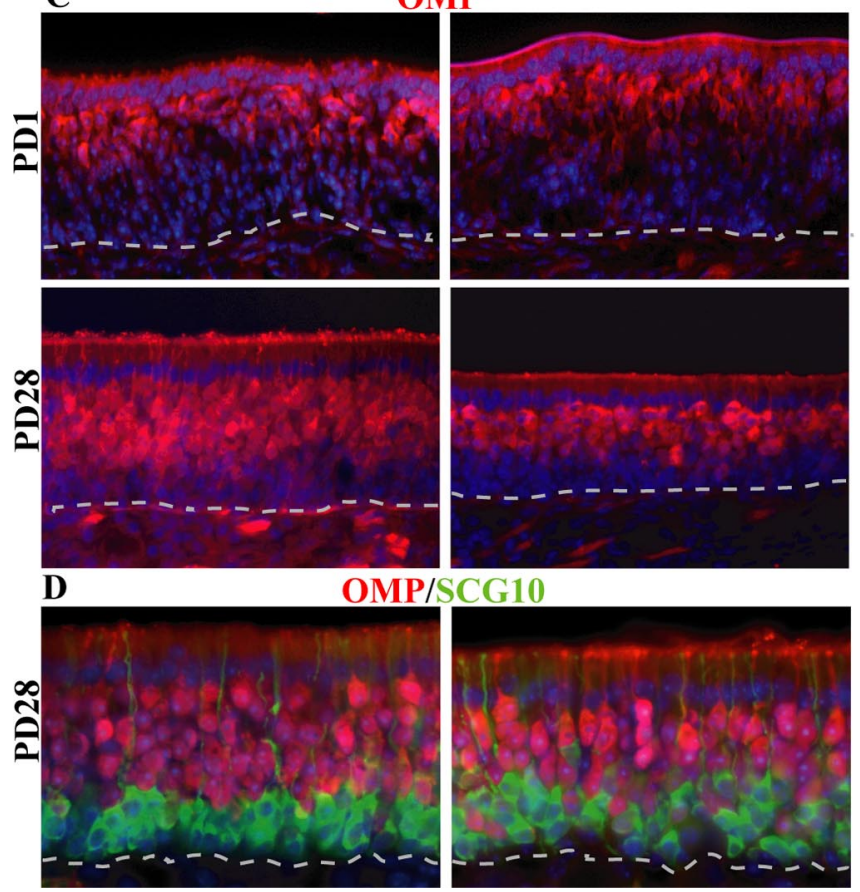

Figure 1. Expression of dominant-negative RAR transgene in OSN. A, Schematic representation of the OMP-dnRAR transgene. A $6 \mathrm{~kb}$ DNA fragment corresponding to the upstream region of the OMP gene was cloned 5' to the coding sequence of RAR $\alpha 403$ and an SV40 polyadenylation site (SV40pA). RAR $\alpha 403$ is a dnRAR that inhibits the function of all RAR isoforms (Damm et al., 1993). $\boldsymbol{B}$, In situ hybridization analyses of consecutive coronal tissue sections of one nasal cavity (dorsal is up, medial is to the left). The hybridization signal (white) was generated with an RAR $\alpha 403$-specific cRNA probe, and sections were from PD43. Bottom panels show a higher magnification of an epithelial region located on the septum (boxed). Indicated is basal lamina (striped lines), lamina propria (LP), the sustentacular cell layer (SUS), OSN layer (OSN), and the basal cell layer (BC) that contains OSN progenitor cells. The dnRAR is expressed in the OSN cell layer throughout the olfactory epithelium in OMP-dnRAR transgenic mice (right) and not in control mice (left). C, Immunohistochemical analyses of olfactory epithelia showing that OMP immunoreactivity in newborn transgenic mice (PD1, top right) is unaltered compared with control mice (top left), whereas it is reduced in transgenic mice at PD28 (bottom right) compared with control mice at the same age (bottom left). D, Double OMP and stathmin/SCG10 immunohistochemical analyses of olfactory epithelial sections at PD28. OMP immunoreactivity (red signal) is reduced in transgenic mice (right) compared with control mice (left), whereas stathmin/SCG10 immunoreactivity (green signal), a marker for immature 0SNs, is equal in control and transgenic mice. Scale bar, $50 \mu \mathrm{m}$. All sections were counterstained with the nuclear dye Hoechst (blue). used (hRAR $\alpha 403$ ) inhibits the function of all RAR isoforms (RAR $\alpha, \operatorname{RAR} \beta$, and $\operatorname{RAR} \gamma$ ), conceivably by forming transcriptionally inactive RAR $\alpha 403$-RXR heterodimers (Damm et al., 1993). The dnRAR lacks the AF2 ligand-dependent transactivation domain and therefore does not mediate induced transcription in response to retinoic acid. However, RXR agonistdependent activation of RAR $\alpha 403-$ RXR heterodimers cannot be excluded (Damm et al., 1993; Johnson et al., 1999). In situ hybridization analyses of transgenic animals, with a dnRAR-specific probe, showed that OMP promoter-driven dnRAR transcripts were, as expected, specifically expressed in the cell layers containing immature and mature OSNs throughout the olfactory epithelium lining the nasal cavity (Fig. $1 \mathrm{~B}$ ). Dividing neural progenitor cells, located in the basal cell layer of the olfactory epithelium, replenish the OSNs that degenerate continuously in the adult animal (Graziadei and Graziadei, 1979; Schwob, 2002). Newly generated immature OSNs migrate upward in the epithelium while accumulating the OMP protein to high steady-state levels. OMP immunohistochemical analyses showed that the olfactory epithelium of OMP-dnRAR and littermate control mice were indistinguishable with regard to cell organization, thickness, and OMP immunoreactivity at postnatal day 1 (PD1) (Fig. 1C). Interestingly, at 1 month of age (PD28), both the epithelial thickness and OMP immunoreactivity were reduced in transgenic mice compared with littermate controls (Fig. 1C). This, together with the fact that dietary vitamin A deficiency has been shown to reduce the number of mature OSNs in adult animals in a similar way (Asson-Batres et al., 2003b), provided strong evidence that retinoid signaling was inhibited because of dnRAR expression. However, in vitamin A-deficient animals, the thickness of the olfactory epithelium is unaltered because of a compensatory increase in the number of immature neurons (Asson-Batres et al., 2003b). Stathmin/SCG10 (SCG10) is a described marker for immature OSNs (Pellier-Monnin et al., 2001). Doubleimmunohistochemistry analysis showed that the OMP-positive cell layer was reduced, whereas the stathmin/SCG10-positive cell layer appeared unaltered in transgenic mice compared with control mice at PD28 (Fig. 1D). These results suggested that the thinner epithelium in the dnRAR-expressing transgenic mice was a consequence of a diminished population of mature OSNs. Interestingly, this postnatal loss of mature neurons was not associated with a corresponding expansion of immature OSNs, which is the case in an olfactory epithelium that regenerates after, e.g., axotomy (Schwob, 2002). To quantify the reduction of OSNs over time, we used the P2-IRES-tauLacZ reporter mouse line. This mouse line is modified to express a bicistronic transcript encoding both the $\mathrm{P} 2$ odorant receptor and $\beta$ gal, which allows for quantification of the number of neurons specified to express one particular odorant receptor (Fig. $2 \mathrm{~A}$ ). Histochemical analyses of epithelial sections of control P2-IRES-tauLacZ mice showed that the number of P2-positive OSNs was increased during the first 2 weeks of postnatal life and declined thereafter (Fig. 2B). These time kinetics correlated with the known expansion of the olfactory epithelium during the first weeks of postnatal life and the following age-dependent diminution of total number of neurons in a given area in normal adult mice and rat (Fung et al., 1997; Weiler and Farbman, 1997). Interestingly, examination of P2IRES-tauLacZ-expressing dnRAR revealed that the number of $\mathrm{P} 2$-positive neurons in the epithelium started to deviate significantly from control mice during the second postnatal week (Fig. $2 B$ ). The number of P2-positive neurons in mice that expressed the dnRAR transgene was found to be reduced by $40-60 \% \mathrm{com}$ pared with control mice from the second week to 6.5 months of 
A OMP-dnRAR X P2-IRES-tauLacZ

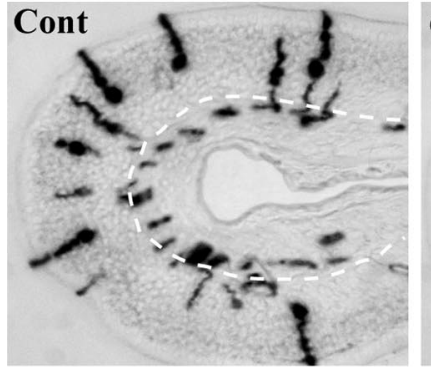
dnRAR

B No of $\mathrm{P} 2$ positive OSNs $\left(x 1^{3}\right)$

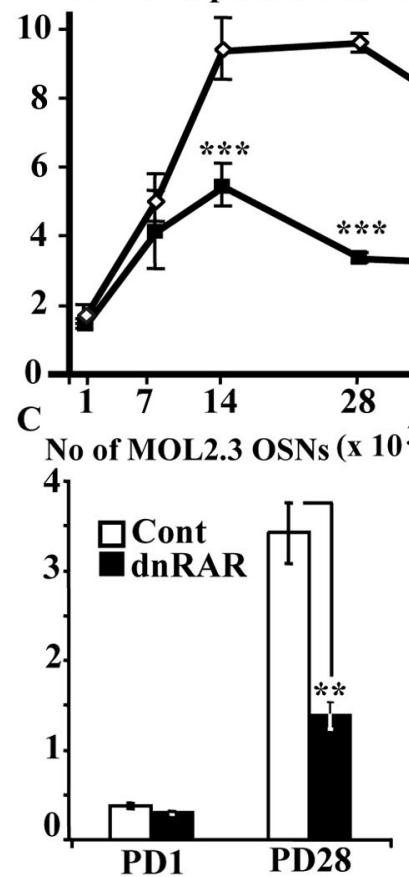

$\diamond$ Cont dnRAR

D

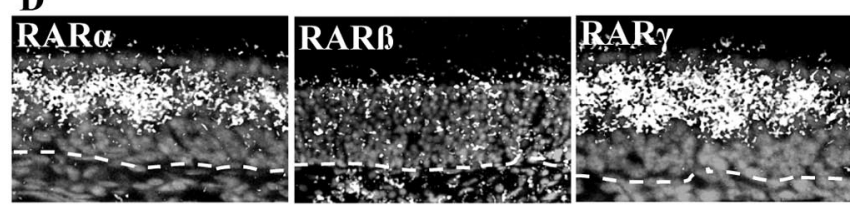

$\mathbf{E}$

OMP-dnRAR X RARE-LacZ
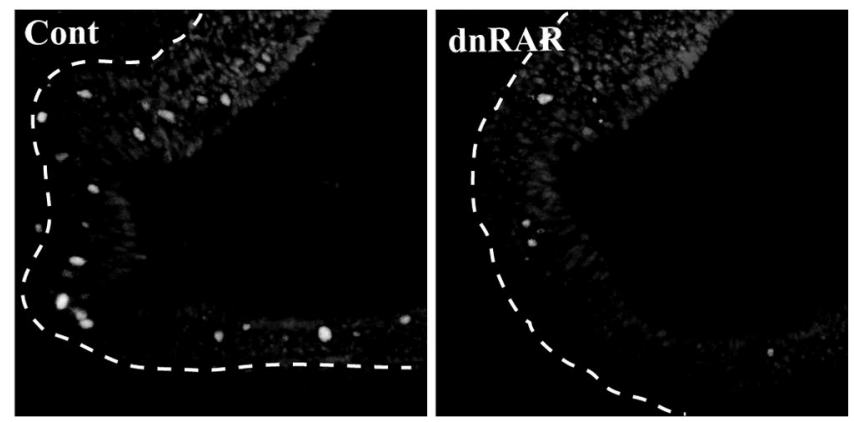

Figure 2. Inhibition of RARE-mediated transcription and loss of odorant receptor-positive OSNs in postnatal and adult mice. $\boldsymbol{A}, \beta \mathrm{gal}$ histochemical staining of OSNs corresponding to those expressing the P2 odorant receptor in P2-IRES-tauLacZ ${ }^{0 /+}$ (Cont) and OMP-dnRAR ${ }^{0 /+} /$ P2-IRES-tauLacZ ${ }^{0 /+}$ (dnRAR) mice at PD28 is shown. $\boldsymbol{B}$, Total number of P2-positive OSNs at different postnatal days is shown. Compared with control mice, P2-positive OSNs in dnRAR mice started to disappear earlier, and their numbers were reduced by $40-60 \%$ between PD7 and PD196. C, The graph to the left shows total number of OSNs expressing the MOL2.3 odorant receptor in MOL2.3-IRES-tauLacZ ${ }^{0 /+}$ (Cont; white bars) and OMP-dnRAR ${ }^{0 /+} / \mathrm{MOL}^{2}$.3-IREStauLacZ ${ }^{0 /+}$ (dnRAR; black bars) mice at PD1 and PD28. Newborn control and dnRAR mice had an equal number of MOL2.3-positive OSNs, whereas the number was reduced in 1-month-old life. Thus, the decrease in number of P2 neurons in the aging olfactory epithelium occurred substantially earlier in the transgenic mice. This decrease did not appear to be attributable to differences in the mechanism leading to postnatal expansion of the system because the kinetics did not differ during the first week of life (Fig. $2 B$ ). These results indicated that OMP-dnRAR transgenic mice were compromised in their ability to recover from an initial wave of postnatal loss of mature OSNs.

The P2 odorant receptor belongs to class II odorant receptors and is expressed in a medial zone of the epithelium, whereas MOL2.3 is a class I odorant receptor that is expressed in a dorsal zone of the epithelium (Mombaerts et al., 1996; Conzelmann et al., 2000). To verify that also class I receptor-expressing OSNs were reduced in number, we analyzed newborn and 1-month-old $($ PD28) progeny from OMP-dnRAR $\times$ MOL2.3-IRES-tauLacZ crosses. The results revealed that the number of MOL2.3-positive OSNs, similar to the P2-positive OSNs, was reduced in 1-monthold OMP-dnRAR mice but was not significantly altered in newborn mice compared with littermates controls (Fig. 2C). This analysis, together with in situ hybridization analyses using probes specific for additional odorant receptors, showed that the zonal pattern of odorant receptor expression was unaltered in OMPdnRAR transgenic mice (supplemental Fig. S1 A, available at www. jneurosci.org as supplemental material).

\section{Expression of dnRAR inhibits RARE-mediated transcription in vivo}

In situ hybridization analyses revealed that endogenous RAR $\alpha$ and RAR $\gamma$ transcripts were highly expressed in cell layers of the epithelium containing mature OSN (Fig. $2 D$ ), whereas RAR $\beta$ transcripts were sparsely distributed in cells of the olfactory epithelium as well as in cells of the lamina propria, underneath the epithelium (Fig. 2D). These results indicated that dnRAR in theory could inhibit the function of endogenous RARs in OSNs. RAR-RXR heterodimers control gene transcription through RAREs. The unaltered number of OSNs in the olfactory epithelium of newborn OMP-dnRAR mice allowed us to address whether dnRAR actually inhibited RARE-mediated gene transcription in OSNs in vivo. To address this issue, we used a transgenic reporter mouse line (RARE-Hsp-LacZ) (Rossant et al., 1991), in which RARE-driven transcription results in the accumulation of $\beta$ gal activity. Histochemical analyses of RARE-HspLacZ mice revealed a scattered distribution of a limited number of $\beta$ gal-positive OSNs in the olfactory epithelium (Fig. 2E). The distribution of $\beta$ gal-positive OSNs was similar to that reported by Whitesides et al. (1998) who used another RARE reporter mouse line to show that OSNs are responsive to endogenous retinoids. Importantly, histochemical analyses of the olfactory epithelium from newborn (PD1) control and dnRAR transgenic mice obtained from OMP-dnRAR $\times$ RARE-Hsp-LacZ crosses showed

OMP-dnRAR mice compared with controls. The graph to the right shows the number of $\beta \mathrm{gal}-$ positive OSNs in newborn (PD1) RARE-LacZ $Z^{0 /+}$ (Cont) and OMP-dnRAR ${ }^{0 /+} /$ RARE-LacZ $^{0 /+}$ (dnRAR) mice. The reduced number of $\beta$ gal-positive cells in newborn OMP-dnRAR mice indicated that dnRAR inhibited RARE-mediated transcription before its effect on OSN number. $\boldsymbol{D}$, In situ hybridization analyses of control mice showing that $\operatorname{RAR} \beta$ (middle) was ubiquitously expressed, whereas the steady-state levels of RAR $\alpha$ (left) and RAR $\gamma$ (right) transcripts were higher in the cell layers containing mature OSNs. E, Shown are representative sections of RAREmediated $\beta$ gal activity in newborn RARE-LacZ ${ }^{\text {o/+ }}$ (Cont) and OMP-dnRAR ${ }^{0 /+} /$ RARE-LacZ $^{0 /+}$ (dnRAR) mice. Sections in $\boldsymbol{D}$ and $\boldsymbol{E}$ were counterstained with the nuclear dye Hoechst (blue). The striped lines outline the basal lamina. All values represent mean and SD. ${ }^{*} p<0.05$, ${ }^{* *} p<$ $0.01,{ }^{* * *} p<0.001$, Student's $t$ test, two tailed. 


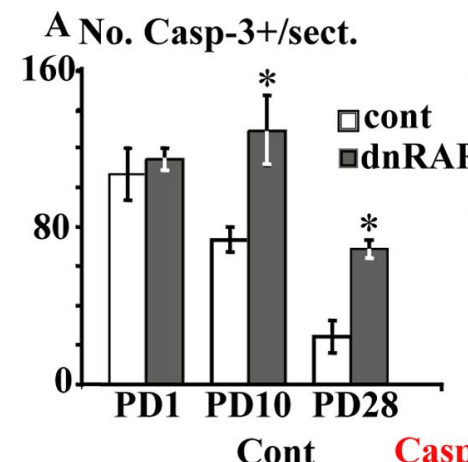

\section{B No. P-H3+/sect.}
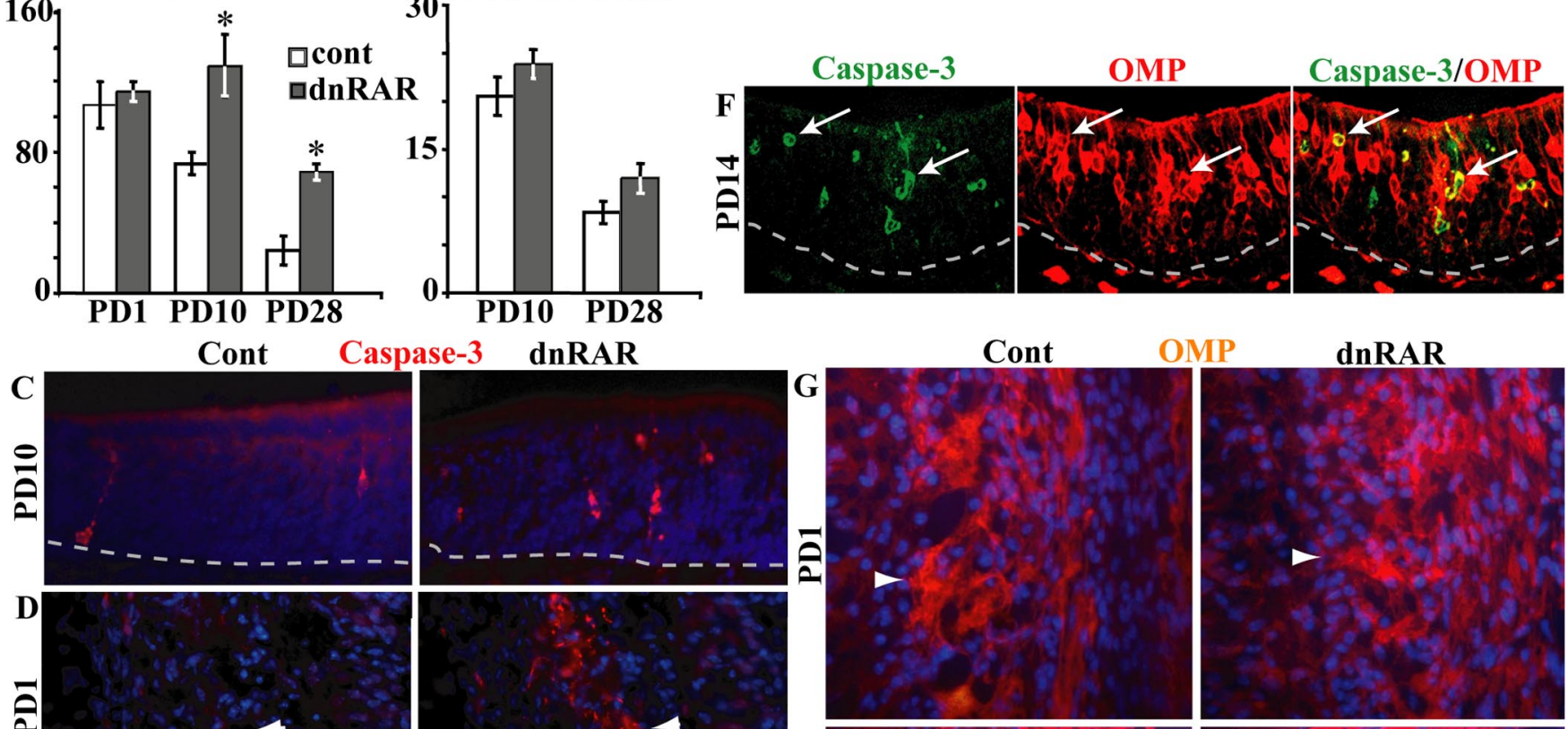

OMP dnRAR
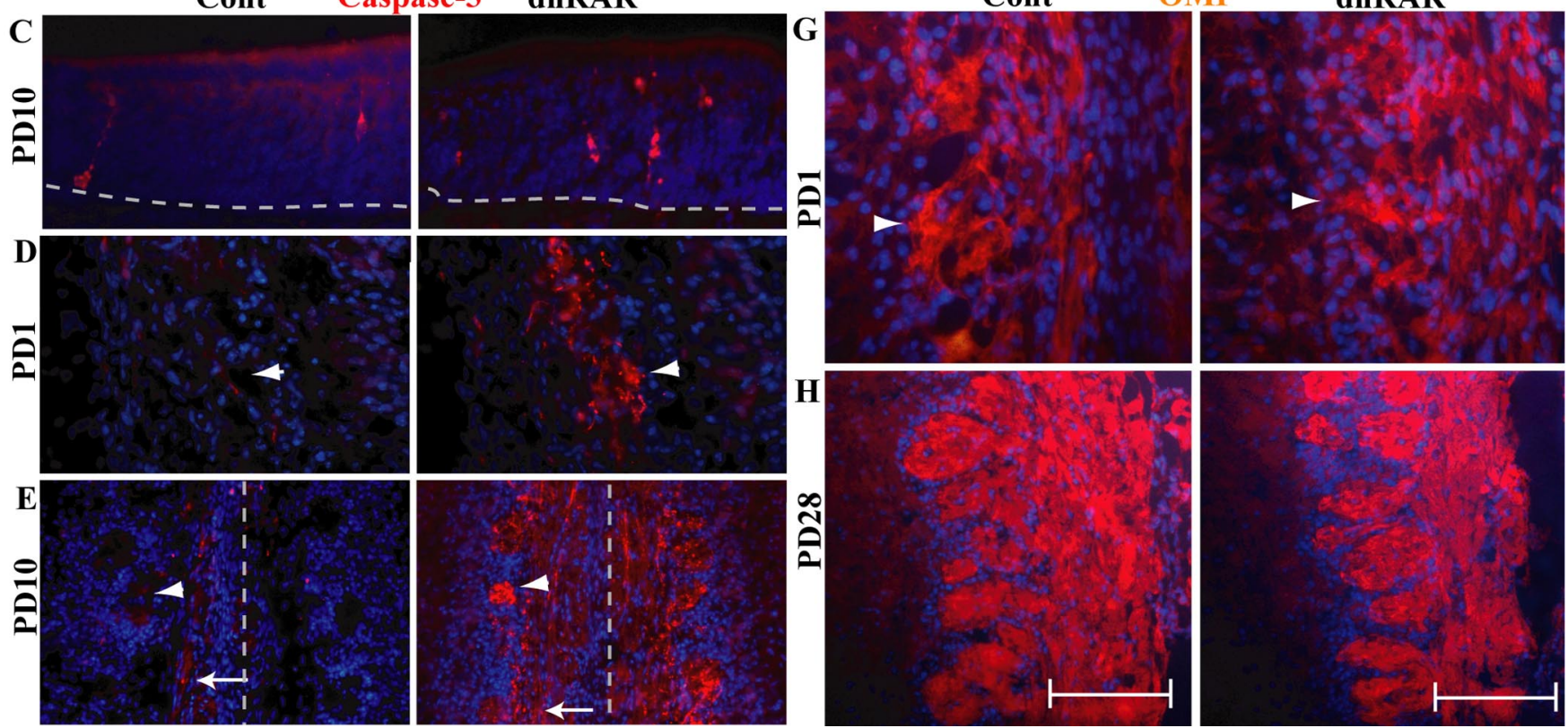

Figure 3. Activation of caspase-3 in 0SN and unaltered proliferation of progenitors. $A, B$, Graphs show numbers of cells per section that were immunoreactive for activated caspase-3 (Casp-3+) or phosphorylated histone $\mathrm{H3}(\mathrm{P}-\mathrm{H} 3+$ ) in control mice (open bars) and OMP-dnRAR (dnRAR, black bars) at different postnatal days. Positive cells located in the progenitor and neuronal cell layers of the olfactory epithelium lining one nasal cavity per animal were quantified. All values represent mean and SD. ${ }^{*} p<0.05$, Student's $t$ test, two tailed. $C-E$, Representative images of activated caspase-3 immunohistochemical analyses of control (left) and OMP-dnRAR (right) mice are shown. C, At PD10, more cells were positive for activated caspase-3 (red signal) in the olfactory epithelium of transgenic mice compared with control mice. Striped lines indicate the basal lamina. D, At PD1, activated caspase-3 immunoreactivity was present in axons forming glomeruli (arrowhead) in the olfactory bulb of transgenic mice, whereas no such immunoreactivity was obtained in axons of control mice. $\boldsymbol{E}$, At PD10, OSN axons in transgenic mice expressed high levels of activated caspase-3 in both the nerve (arrow) and glomerular (arrowhead) layers of the olfactory bulb. The nerve layer of control mice stained weakly for activated caspase-3 at PD10 (arrow, left). $\boldsymbol{F}$, Confocal images of caspase-3- and OMP-positive cells in the epithelium of dnRAR transgenic mice at PD14. Striped lines indicate the basal lamina, and the arrows indicate cells that are positive for both caspase-3 and OMP. $\mathbf{G}, \boldsymbol{H}$, Representative images of OMP immunohistochemical analyses of control (left) and OMP-dnRAR (right) mice. The OMP immunoreactivity of axons forming glomeruli in newborn (PD1) control and transgenic mice were similar. At PD28, the organization of OMP-positive axons in the nerve and glomerular layers were similar in control and transgenic mice, although less OMP immunoreactivity, in particular in the nerve layer (bar), indicated that the axonal input was reduced in transgenic mice. All sections were counterstained with the nuclear dye Hoechst (blue).

that the expression of dnRAR corresponded to a $60 \%$ reduction in the number of $\beta$ gal-positive OSNs (Fig. 2C). The observation that RARE-driven $\beta$ gal expression was reduced in newborn transgenic mice before the observed decline in OSN numbers suggested that dnRAR directly inhibited RARE-mediated transcription.

Repression exerted by unliganded retinoid receptors has been shown to be essential for certain developmental processes (Weston et al., 2003). Our result did not discriminate between the possibilities that dnRAR increased repression or decreased ligand-dependent activation of RARE-dependent transcription. However, because repression and ligand-dependent activation are mechanistically linked, these result indicated that dnRAR inhibited nuclear retinoid signaling.

Caspase-3 activation and absence of compensatory progenitor cell proliferation

To address whether the reduction of OSNs coincided with increased apoptosis, we performed immunohistochemical analyses for activated (cleaved) caspase-3. Quantification of activated caspase-3-positive OSNs in newborn mice showed that the numbers were similar in OMP-dnRAR and littermate control mice (Fig. $3 A$ ). In agreement with the observed loss of OSNs in OMPdnRAR during the second postnatal week, we found that transgenic mice at this age (PD10) had a significantly increased number of caspase-3-positive OSNs compared with controls (Fig. $3 A, C)$. At 1 month of age, this difference was even more pronounced (Fig. 3A). To analyze whether proliferation of progenitors was altered by dnRAR, we used the mitosis marker phosphoH3. Quantification of phospho-H3-positive cells in the olfactory epithelium revealed no significant difference in the number of mitotic cells in transgenic versus control mice at either PD10 or PD28 (Fig. 3B). To further examine the effects of dnRAR on cell proliferation, we quantified BrdU-positive nuclei in the basal and neural cell layers of the olfactory epithelium. The numbers of BrdU-positive nuclei per millimeter epithelium in control mice at PD7, PD14, and PD35 were $302 \pm 24.9,256 \pm 31.8$ and $106 \pm$ 
OMP-dnRAR X P2-IRES-tauLacZ
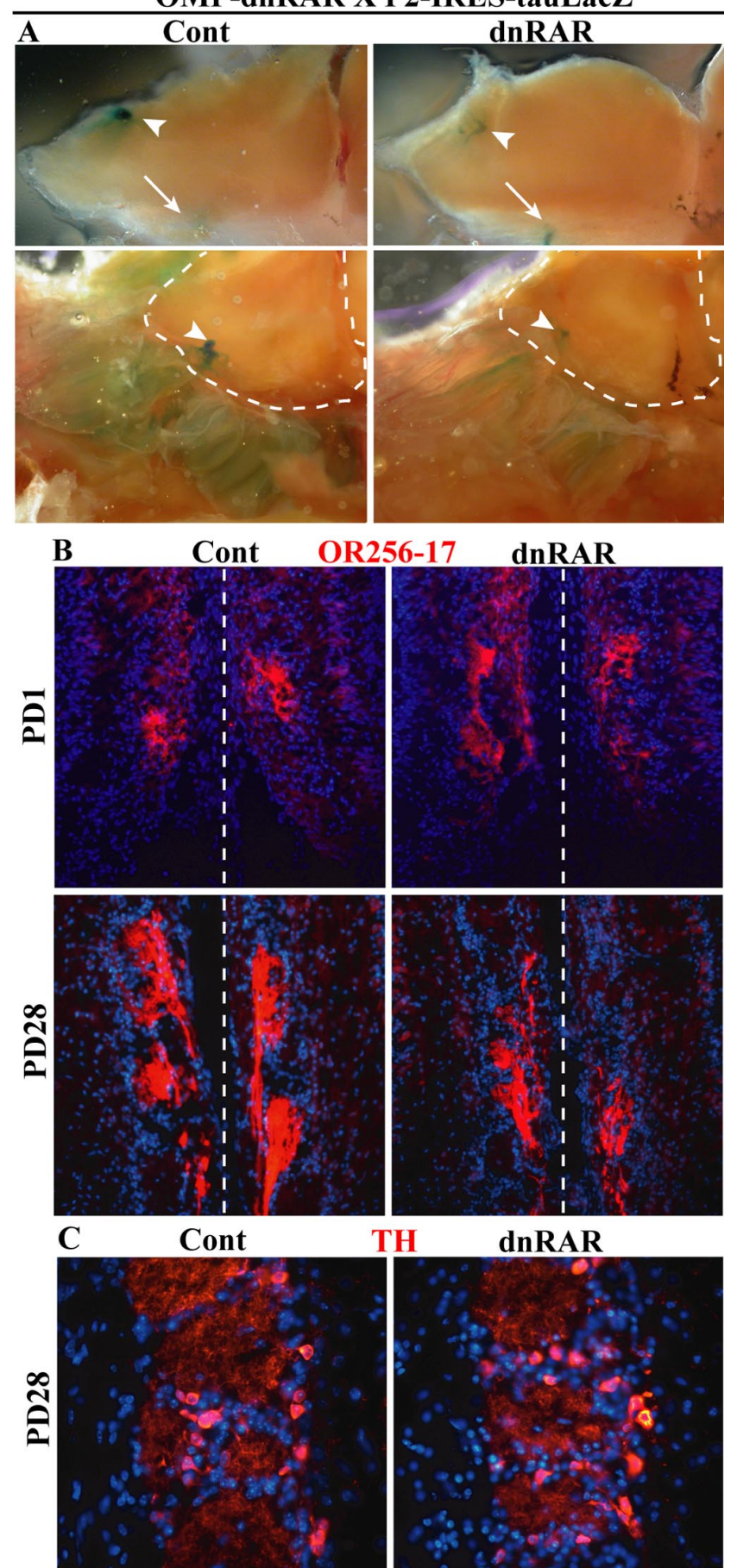

TH

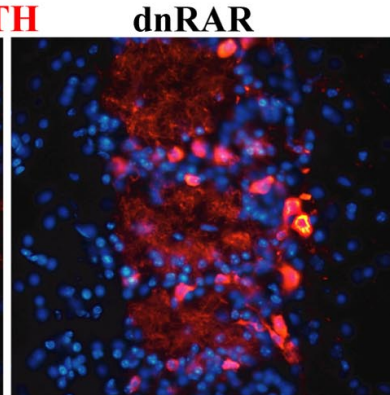

Figure 4. Unaltered odorant receptor-specific axonal projections and postsynaptic TH immunoreactivity in OMP-dnRAR transgenic mice. A, Whole-mount $\beta$ gal histochemical analyses of control (Cont) and OMP-dnRAR (dnRAR) mice carrying a P2-IRES-tauLacZ transgenic allele. The top rows show dorsal views (anterior to the left) of the right olfactory bulb with lateral (arrowhead) and medial (arrow) glomeruli that are innervated by $\beta$ gal-positive axons of OSNs expressing the $\mathrm{P} 2$ odorant receptor gene. The bottom row panels shows lateral views of the left olfactory bulb (demarcated by a striped line) with P2-specific lateral glomeruli (arrowhead). Control and transgenic mice did not differ in convergence of P2-specific axons to topographically defined glomeruli. $\boldsymbol{B}$, Shown are immunohistochemical analyses of the medial part of the olfactory bulb glomerular layer with antibodies that recognize one specific odorant receptor (m0R256-17). OSN axons expressing m0R256-17 (red signal) converged to glomeruli located at similar positions in the left and right hemispheres (striped lines indicate the midline) in both newborn (PD1) and 4-week-old (PD28) mice. The patterns of odorant-specific convergence were similar in control and OMP-dnRARtransgenic mice. C, Shown are immunohistochemical analyses for $\mathrm{TH}$, which is expressed in an activity-dependent manner in postsynaptic periglomerular cells. TH immunoreactivity was not significantly reduced in 1-month-old (PD28) OMP-dnRAR compared with control mice. All sections were counterstained with the nuclear dye Hoechst (blue).
13.6, respectively. The corresponding numbers for dnRAR transgenic mice were similar: $316 \pm 45.5,274 \pm 24.2$, and $107 \pm 16$, respectively. Collectively, these results indicated that the decreased number of OSNs in adult dnRAR transgenic mice was attributable to increased cell death, which was not compensated for by increased progenitor cell proliferation.

\section{Activation of caspase-3 in OSN axon terminals of newborn transgenic mice}

Recent studies have shown that OSNs undergo caspase-mediated retrograde apoptosis after nerve transection or target cell ablation, during which an initial caspase-3 activation in axons is followed by apoptosis of OSN cell bodies (Fung et al., 1997; Cowan et al., 2001). To investigate whether the dnRAR-induced cell death that we observed occurred by a similar mechanism, we analyzed OSN axons at the level of the olfactory bulb for the presence of activated caspase-3. In newborn transgenic mice, but not littermate controls, we found activated caspase- 3 immunoreactivity in the axon terminals in the forming glomeruli (Fig. 3D). At PD10, the caspase-3 immunoreactivity in transgenic mice was even more pronounced and was detected in the glomerular layer of the olfactory bulb and in the nerve layer (Fig. 3E, right). A faint signal was also present in the nerve layer of the olfactory bulb in control mice (Fig. $3 E$, left). The presence of activated caspase- 3 in axon terminals several days before the accumulation of activated caspase- 3 in the cell bodies (Fig. $3 A$ ) indicated that the mechanism of OSN death caused by decreased RAREdependent transcription resembled the retrograde-driven type of death that has been reported to occur after nerve transection, olfactory bulbectomy, and target cell deprivation (Fung et al., 1997; Cowan et al., 2001). Results of double-immunohistochemical analyses by confocal microscopy (Fig. $3 F$ ) revealed that 55 and $73 \%$ of caspase-3-positive cells in the olfactory epithelium at PD14 were immunopositive also for OMP in control and dnRAR transgenic mice, respectively. The increased ratio of caspase-3/OMP-double positive cells together with the initial appearance of activated caspase-3 in axon terminals suggested that inhibition of RAREdependent transcription influenced survival of mature OSNs that had reached target neurons in the olfactory bulb.

\section{OSNs in OMP-dnRAR mice show unaltered axonal targeting} We next addressed whether the increased death of mature OSNs in OMP-dnRAR mice coincided with incorrect axonal targeting. OMP (Fig. 3G,H) and synaptophysin (data not shown) immunohistochemical analyses of mice at PD1 and PD14 showed that the overall organization of the nerve layer and the glomerular layer of the olfactory bulb were similar in transgenics and controls. However, in accordance with the increased death of mature OSNs, the nerve layer was relatively thinner in adult transgenic mice than in littermate controls (Fig. $3 H$ ). Axons with the same odorant receptor specificity are organized into the same few glomeruli. To visualize the topography of odorant receptor-specific projections, we analyzed whole-mount preparations from the progeny of OMP-dnRAR $\times$ P2-IRES-tauLacZ crosses. These analyses revealed a similar pattern of axonal convergence of the P2 OSN subpopulation to laterally and medially located glomeruli in the olfactory bulb of OMP-dnRAR transgenic and control mice at PD48 (Fig. 4A). Analyses of progeny from OMPdnRAR $\times$ MOL2.3-IRES-tauLacZ crosses gave the same result (data not shown). Analyses with antibodies that recognize one specific odorant receptor [mOR256-17 (Strotmann et al., 2004)] confirmed that OSN axons expressing the same receptor converged to topographically defined glomeruli in both newborn (PD1) and 1-month-old (PD28) OMP-dnRAR transgenic mice 

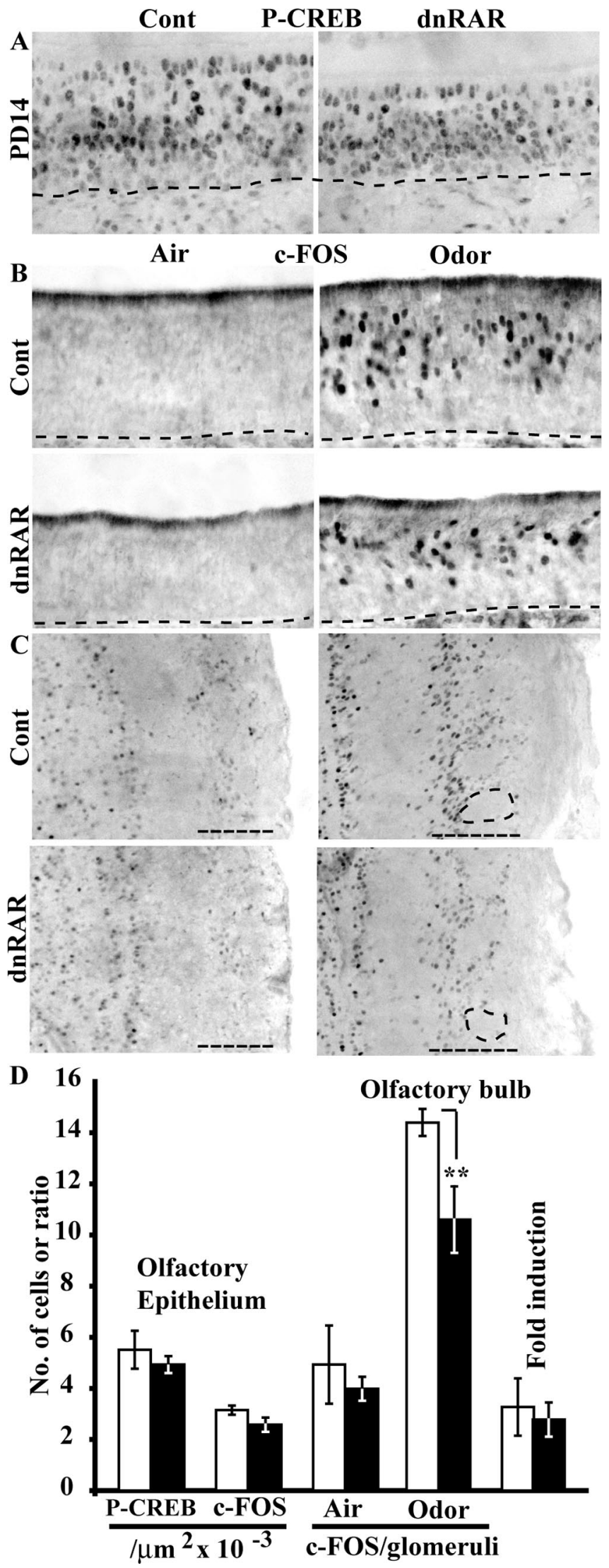

Figure 5. OSNs expressing dnRAR are not altered in signaling pathways associated with OSN survival and odorant receptor activity. $\boldsymbol{A}, \boldsymbol{B}$, Immunohistochemical analyses of the olfactory epithelium in 2-week-old control (Cont) and OMP-dnRAR (dnRAR) mice for phosphorylated CREB (P-CREB) and C-Fos are shown. Striped lines indicate the basal lamina. $\boldsymbol{A}$, The frequency of phospho-CREB-positive OSNs was similar in control and transgenic mice (see also $D$ ).
(Fig. $4 B$ ). We interpreted these results to indicate that inhibition of RARE-dependent transcription did not cause receptor-specific OSN subpopulations to innervate an excessive number of glomeruli and, hence, that incorrect axonal targeting was unlikely to underlie the increased death rate of mature OSNs.

\section{Expression of neural activity markers is not changed in OMP-dnRAR mice}

To examine for the possibility that the increased death of OSNs in postnatal OMP-dnRAR mice was associated with a general decrease in odor-stimulated signaling, immunohistochemical analyses for proteins known to show an altered expression in response to neural activity was performed. The expression of $\mathrm{TH}$ in postsynaptic periglomerular cells in the olfactory bulb is downregulated several weeks after naris occlusion as well as in mice lacking an olfactory cyclic nucleotide-gated channel subunit gene required for odor-stimulated activity in the majority of OSNs (Baker et al., 1999). However, TH immunoreactivity in periglomerular cells was not significantly reduced in OMP-dnRAR at PD28 compared with littermate controls at PD28 (Fig. 4C). This suggested that mature OSNs in dnRAR transgenic were able to activate postsynaptic target cells. Another event associated with odorant receptor activation as well as neural survival is CREB phosphorylation (Watt et al., 2004). Our examination of the OSN epithelial layer at PD10 showed that OMP-dnRAR and control mice displayed a similar pattern and frequency of phosphoCREB-immunoreactive cells (Fig. $5 A, D$ ). This result indicated that expression of dnRAR did not inhibit a signaling pathway that has been implicated in OSN survival and odorant receptor activity. We have shown previously that exposing mice to an odor elicits increased c-Fos expression in different populations of mature OMP-positive OSNs depending on odor used, suggesting that c-Fos reflects cellular events regulated by odorant receptor stimulation (Norlin et al., 2005). Exposure of 2-week-old (PD14) mice for $10 \mathrm{~min}$ to pyridine resulted in a robust induction of c-Fos in both transgenic and control mice (Fig. $5 B, D$ ). The unaltered induction of c-Fos in response to an odor indicated that dnRAR did not inhibit odor-induced intracellular signaling. A marked induction of c-Fos was also evident in fractions of target cells in the periglomerular cells layers of olfactory bulb in both OMP-dnRAR and control mice (Fig. 5C,D). The $27 \pm 4 \%$ decrease in c-Fos-positive periglomerular cells observed in exposed transgenic mice, compared with control mice, most likely reflected the reduced axonal input in transgenic mice attributable to the increased death of OSNs at PD14. Importantly, the fold induction of c-Fos-positive periglomerular cells (odor exposure/ air exposure) (Fig. 5D) was similar in control and transgenic mice, which indicated that OSNs expressing dnRAR were able to activate postsynaptic target cells in response to odor.

\footnotetext{
$\boldsymbol{B}$, Expression of c-Fos in the olfactory epithelium of unexposed (air) and odor-exposed (pyridine) mice. Odor stimulation for 10 min induced c-Fos expression in scattered OSNs of control (Cont) and OMP-dnRAR (dnRAR) mice to a similar degree (see also D). C, Immunohistochemical analyses showing odor-induced c-Fos induction in the periglomerular cell layer (striped line, glomerulus striped circle) of 2-week-old mice. The number of c-Fos-positive periglomerular cells was reduced in transgenic mice, most likely attributable to reduced axonal input, whereas the fold induction (odor/air) was similar in control and transgenic mice (see also $\boldsymbol{D}$ ). $\boldsymbol{D}$, Graphs represent quantifications of phospho-CREB- or c-Fos-positive cells as exemplified in $\boldsymbol{A}-\boldsymbol{C}$. The fold induction of $\mathrm{c}$-Fos expression represents the ratio between c-Fos-positive periglomerular cells quantified before and after odor stimulation. All values represent mean and SD. ${ }^{* *} p<$ 0.01 , Student's $t$ test, two tailed.
} 


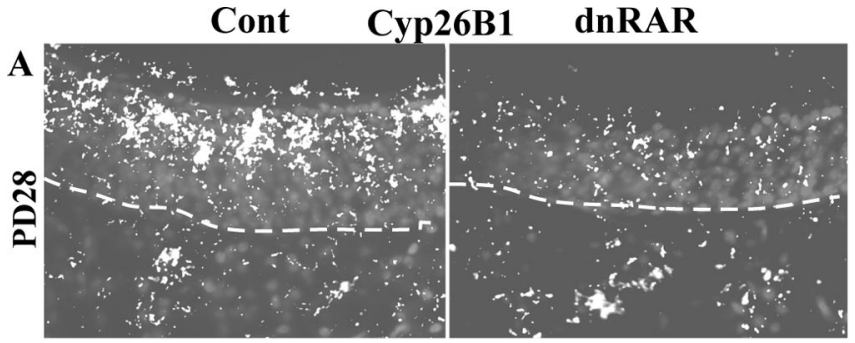

B

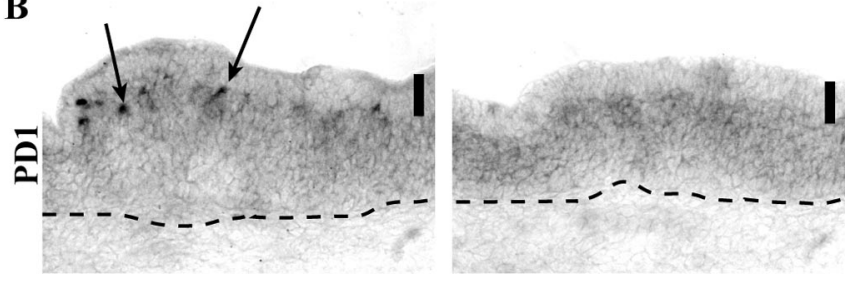

Figure 6. dnRAR-regulated expression of Cyp26B1 in OSNs. A, In situ hybridization analysis of the olfactory epithelium of 1-month-old (PD28) control (Cont) and OMP-dnRAR transgenic (dnRAR) mice with a Cyp26B1-specific radioactive probe. In control mice, the hybridization signal (in white) was most intense in the cell layer containing mature OSNs that is located close to the apical, sustentacular cell layer. In transgenic mice, the hybridization signal was reduced. The sections were counterstained with the nuclear dye Hoechst (gray). $\boldsymbol{B}$, In situ hybridization analysis of the olfactory epithelium of newborn (PD1) mice with a digoxygenin-labeled Cyp26B1 probe. The probe hybridized to a limited number of OSNs (arrows) in control mice but not transgenic mice. 0SNs expressing Cyp26B1 in control mice were located just underneath the sustentacular cell layer (indicated with a bar).

\section{A fraction of mature OSNs express the retinoid-degrading enzyme Cyp26B1 in an RAR-dependent manner}

Conceivably, RALDH-expressing cells in the primary olfactory system produce retinoids that OSN receive via their cell bodies and/or axons (Norlin et al., 2001; Niederreither et al., 2002; Wagner et al., 2002). Localized retinoid degradation mediated by the Cyp26 subfamily of cytochrome P450 enzymes provides one mechanism to regulate retinoid homeostasis spatially within a tissue (McCaffery et al., 1999; Reijntjes et al., 2005). Because our results indicated that OSNs required nuclear retinoid signaling for their prolonged survival, an interesting possibility was that retinoid homeostasis normally influences the lifespan of mature OSNs. Interestingly, in situ hybridization analyses of control mice at PD28 revealed that OSNs, located in the apical neuronal cell layer of the epithelium, expressed high levels of Cyp26B1 mRNA (Fig. 6A). Moreover, Cyp26B1-positive OSNs were absent in OMP-dnRAR mice (Fig. 6A). In situ hybridization of newborn (PD1) mice with a digoxygenin-labeled Cyp26B1 probe showed that control mice had a limited number of OSNs (39 \pm 7.9 per section), located close to the sustentacular cell layer, that expressed high levels of Cyp26B1 mRNA, whereas no expression was detected in dnRAR transgenic mice (Fig. 6B). Because newborn transgenic and control mice were found to have an equal number of OSNs, the result suggested that Cyp26B1 expression in the transgenic mice was abolished because of dnRARmediated inhibition of Cyp26B1 transcription.

\section{Discussion}

We show here that inhibition of retinoid signaling selectively in OSNs in vivo results in death of mature OSNs subsequent to the development of the olfactory sensory map. One important implication of this result is that it is possible to experimentally separate a retinoid-regulated survival mechanism that operates at a late stage of neural circuit formation, or during maintenance of established connections, from retinoid-regulated mechanisms that influence survival of neurons during early stages, e.g., during neurogenesis, establishment of neuronal identity, and formation of precise axonal projection patterns (Sockanathan et al., 2003; Wang et al., 2005). This finding is particularly relevant in light of studies that have demonstrated a fundamental role of retinoid signaling for the maintenance of mature brain function (Chiang et al., 1998; Etchamendy et al., 2001; Misner et al., 2001; Goodman and Pardee, 2003). It is also noteworthy that studies have shown that the amyloid precursor protein, which is involved in the pathogenesis of Alzheimer's disease, normally promotes postdevelopmental neurite arborization (Leyssen et al., 2005) and that a $\gamma$-secretase generated fragment of the amyloid precursor protein has been shown to inhibit RARE-mediated transcription in vitro (Gao and Pimplikar, 2001).

The fact that dnRAR expression reduces the number of OMPpositive OSNs supports the conclusion that mature OSNs are specifically targeted for death in retinoid-depleted tissue (AssonBatres et al., 2003b). However, in retinoid-depleted animals, a compensatory increase in OSN progenitor proliferation is observed (Asson-Batres et al., 2003b). Importantly, dying OSNs in OMP-dnRAR mice do not induce such an increase in cell division. Moreover, the total number of OSNs (immature plus mature) is unaltered in vitamin A-deficient rats, whereas it is reduced in adult OMP-dnRAR mice. Absence of a compensatory increase in progenitor cell proliferation in OMP-dnRAR mice indicates that OSN death rate per se does not determine the rate of progenitor cell proliferation. A similar conclusion has arisen from a study of transgenic mice with OSNs that express the antiapoptotic gene BclII under the control of the OMP promoter (Hayward et al., 2004). In these mice, OSNs show an increased half-life after olfactory bulb ablation, without causing a relative decrease in progenitor cell proliferation. The increase of progenitor cell proliferation in vitamin A-deficient animals and the absence of a compensatory increase in progenitor cell proliferation in OMP-dnRAR mice also open up the interesting possibility that a distinct retinoid-dependent mechanism regulates progenitor cell proliferation. Evidence that OMP-negative cells in the olfactory epithelium indeed are responsive to retinoids is supported by the scattered expression of RAR $\beta$ together with the presence of $\beta$ gal-positive cells in the sustentacular and basal cell layer of the olfactory epithelium, as well as in the in lamina propria of RAREHsp-LacZ mice. Moreover, CRABP-II has been shown to be selectively expressed in a subset of basal cells and in the sustentacular cells (Asson-Batres et al., 2003a). An alternative, but not mutually exclusive, hypothesis is that vitamin A deficiency influences neurogenesis in an RXR-dependent manner. RXRs regulate transcription as homodimers or by forming heterodimers with other nuclear receptors, and a neuroprotective function of endogenous RXR ligands that is mediated by Nurr1-RXR heterodimers occurs in the embryonic nervous system (WallenMackenzie et al., 2003). However, it remains to be determined whether neurogenesis in the olfactory epithelium is regulated by RXR-specific agonists. In any case, our results suggest that an important function of retinoids in the primary olfactory system is to prolong survival of mature OSNs to maintain the differentiated (adult) population of connected OSNs.

Neural activity is central to OSN survival and several aspects of olfactory map refinement and maintenance (Zhao and Reed, 2001; Nakatani et al., 2003; Watt et al., 2004; Yu et al., 2004; Zou et al., 2004). We find that OSNs expressing dnRAR are normal with regard to cellular events that are associated with odorant receptor signaling, i.e., postsynaptic TH expression (Baker et al., 1999), CREB phosphorylation, and odor-induced presynaptic 
and postsynaptic expression of c-Fos (Watt et al., 2004; Norlin et al., 2005). Moreover, the phenotype of OMP-dnRAR mice is not similar to mice that are deficient in a cyclic nucleotide-gated channel subunit that is essential for odor-evoked activity (Baker et al., 1999), neither is the phenotype similar to that of mice genetically altered to express genes that diminish OSN excitability or synaptic release (Yu et al., 2004). Collectively, these findings indicate that the effect of retinoids on OSNs is mechanistically separate from positive effects of neural activity on cell survival.

There is evidence that OSN death induced after axonal damage or target deprivation is driven by retrograde propagation of activated caspase- 3 from axon terminals to the cell bodies (Cowan et al., 2001; Cowan and Roskams, 2004). Interestingly, activated caspase- 3 is present in axon terminals several days before its appearance in the OSN cell bodies of OMP-dnRAR mice. This result points to a connection between death caused by dnRAR expression and death caused by disruption of synaptic contacts. Caspase-3 activation by cell intrinsic or extrinsic pathways, associated with acute as well as chronic neurodegenerative disorders, is typically viewed as the final event of the cell death cascade. However, evidence now suggests that transient and localized nonapoptotic caspase-3 activation is required for normal cell function, e.g., during growth cone regeneration, synaptic remodeling, and circuit refinement (McLaughlin, 2004; Verma et al., 2005). It is thus possible that reduced retinoid signaling results in premature and/or enhanced levels of activated caspase-3 that normally is required transiently and in limited amounts during a plastic phase of neural circuit formation. Aberrant axonal OSN projections, formed during embryonic development, disappear during the first 2-3 weeks of postnatal life (Nakatani et al., 2003; Zou et al., 2004). This postnatal phase of refinement thus coincides with a massive increase of activated caspase- 3 in axons and death of OSNs in OMP-dnRAR transgenic mice. Interestingly, maintenance of aberrant OSN projections correlates with prolonged OSN survival (Zou et al., 2004).

Conceivably, inhibition of retinoid signaling changes the activity of a protein(s), which regulates the extent, duration, and/or retrograde transport of activated caspase- 3 in the axons. The recent identification of dynactin-mediated retrograde transport of activated initiator caspase- 8 and the finding that $\mathrm{p} 75$, the lowaffinity NGF receptor, may function as an upstream death receptor in the mechanism leading to retrograde apoptosis of OSNs provides an interesting starting point for the identification of such protein(s). Additional candidate proteins are Trk and glial cell line-derived neurotrophic factor receptors that influence the survival of cultured embryonic sympathetic neurons in a retinoid-dependent manner (Plum et al., 2001; Doxakis and Davies, 2005).

Conceivably, retinoids are produced by RALDH-positive cells in nerve sheaths, meninges, and periglomerular cells of the olfactory bulb (Norlin et al., 2001; Niederreither et al., 2002; Wagner et al., 2002), and it has been suggested that CRABP-I in OSN axons capture and transport retinoic acid to the OSN nucleus (Gustafson et al., 1999; Asson-Batres et al., 2003a). The possibility that cells in the proximity of OSN axons may be a source of retinoids essential for OSN survival is interesting considering the special attention paid to the capacity of cells in the olfactory nerve to stimulate repair after transplantation into areas of spinal cord injury (Mackay-Sim, 2005). Moreover, studies of OSN turnover after olfactory bulb ablation have established that OSNs are trophically dependent on the olfactory bulb for their prolonged survival. The neuroprotective factor(s) mediating this effect has not been identified. Because RALDH-positive cells are also de- pleted after olfactory bulb ablation, it is interesting to speculate that retinoids may be such a trophic factor required. However, these hypotheses do not exclude the possibility that retinoid production by RALDH-positive cells in the vicinity of mature OSN cell bodies in the epithelium contributes to OSN survival. A study of chicken OSNs has shown that embryonic OSNs are more resistant than postnatal neurons to apoptosis caused by axotomy (Mathonnet et al., 2002). This result was interpreted to be attributable to a greater plasticity of embryonic neurons and that embryonic and postnatal OSNs may depend differently on local and target-derived factors. Such an interpretation may also account for the differential sensitivity of embryonic and postnatal OSNs to dnRAR expression. In this respect, it is particularly interesting that embryonic and postnatal olfactory epithelium have been shown to differ with regard to both the level and the distribution of RALDH expression (Niederreither et al., 2002). Whereas RALDHs produce retinoic acid, it is currently thought that catabolic Cyp26 enzymes mediate negative feedback control of retinoic acid signaling. We find that Cyp26B1 is expressed in a subpopulation of OSNs, located just underneath the sustentacular cell layer, and that the expression of this enzyme decreases before the effect of dnRAR expression on cell survival. This result is in accordance with studies that have shown $\operatorname{RAR} \alpha$-dependent induction of Cyp26B1 expression (Reijntjes et al., 2005). Because the activity of Cyp26B1, like dnRAR, inhibits retinoic acid function, it possible that the Cyp26B1-positive OSNs in postnatal and adult normal mice are more vulnerable to die in response to events that lead to caspase- 3 activation in axons. The death induced by dnRAR may therefore pertain to the way by which the number of mature OSNs is controlled normally.

In summary, our results provide the first in vivo evidence for a direct role of retinoid signaling in the survival of mature neurons in the postnatal and adult animal. The results also indicate that homeostatic control of retinoids can directly influence the population size of functional neurons with established axonal projections. Thus, our results are consistent with a role for defective retinoid signaling in neurodegenerative disease.

\section{References}

Alenius M, Bohm S (2003) Differential function of RNCAM isoforms in precise target selection of olfactory sensory neurons. Development 130:917-927.

Asson-Batres MA, Ahmad O, Smith WB (2003a) Expression of the cellular retinoic acid binding proteins, type II and type I, in mature rat olfactory epithelium. Cell Tissue Res 312:9-19.

Asson-Batres MA, Zeng MS, Savchenko V, Aderoju A, McKanna J (2003b) Vitamin A deficiency leads to increased cell proliferation in olfactory epithelium of mature rats. J Neurobiol 54:539-554.

Baker H, Cummings DM, Munger SD, Margolis JW, Franzen L, Reed RR, Margolis FL (1999) Targeted deletion of a cyclic nucleotide-gated channel subunit (OCNC1): biochemical and morphological consequences in adult mice. J Neurosci 19:9313-9321.

Chambon P (1996) A decade of molecular biology of retinoic acid receptors. FASEB J 10:940-954.

Chiang MY, Misner D, Kempermann G, Schikorski T, Giguere V, Sucov HM, Gage FH, Stevens CF, Evans RM (1998) An essential role for retinoid receptors RARbeta and RXRgamma in long-term potentiation and depression. Neuron 21:1353-1361.

Conzelmann S, Levai O, Bode B, Eisel U, Raming K, Breer H, Strotmann J (2000) A novel brain receptor is expressed in a distinct population of olfactory sensory neurons. Eur J Neurosci 12:3926-3934.

Corcoran J, So PL, Maden M (2002) Absence of retinoids can induce motoneuron disease in the adult rat and a retinoid defect is present in motoneuron disease patients. J Cell Sci 115:4735-4741.

Corcoran JP, So PL, Maden M (2004) Disruption of the retinoid signalling pathway causes a deposition of amyloid beta in the adult rat brain. Eur J Neurosci 20:896-902. 
Cowan CM, Roskams AJ (2004) Caspase-3 and caspase-9 mediate developmental apoptosis in the mouse olfactory system. J Comp Neurol 474:136-148.

Cowan CM, Thai J, Krajewski S, Reed JC, Nicholson DW, Kaufmann SH, Roskams AJ (2001) Caspases 3 and 9 send a pro-apoptotic signal from synapse to cell body in olfactory receptor neurons. J Neurosci 21:7099-7109.

Crandall J, Sakai Y, Zhang J, Koul O, Mineur Y, Crusio WE, McCaffery P (2004) 13-cis-retinoic acid suppresses hippocampal cell division and hippocampal-dependent learning in mice. Proc Natl Acad Sci USA 101:5111-5116.

Damm K, Heyman RA, Umesono K, Evans RM (1993) Functional inhibition of retinoic acid response by dominant negative retinoic acid receptor mutants. Proc Natl Acad Sci USA 90:2989-2993.

Danciger E, Mettling C, Vidal M, Morris R, Margolis F (1989) Olfactory marker protein gene: its structure and olfactory neuron-specific expression in transgenic mice. Proc Natl Acad Sci USA 86:8565-8569.

Doxakis E, Davies AM (2005) Retinoic acid negatively regulates GDNF and neurturin receptor expression and responsiveness in embryonic chicken sympathetic neurons. Mol Cell Neurosci 29:617-627.

Etchamendy N, Enderlin V, Marighetto A, Vouimba RM, Pallet V, Jaffard R, Higueret P (2001) Alleviation of a selective age-related relational memory deficit in mice by pharmacologically induced normalization of brain retinoid signaling. J Neurosci 21:6423-6429.

Fung KM, Peringa J, Venkatachalam S, Lee VM, Trojanowski JQ (1997) Coordinate reduction in cell proliferation and cell death in mouse olfactory epithelium from birth to maturity. Brain Res 761:347-351.

Gao Y, Pimplikar SW (2001) The gamma-secretase-cleaved C-terminal fragment of amyloid precursor protein mediates signaling to the nucleus. Proc Natl Acad Sci USA 98:14979-14984.

Goodman AB, Pardee AB (2003) Evidence for defective retinoid transport and function in late onset Alzheimer's disease. Proc Natl Acad Sci USA 100:2901-2905.

Graziadei PP, Graziadei GA (1979) Neurogenesis and neuron regeneration in the olfactory system of mammals. I. Morphological aspects of differentiation and structural organization of the olfactory sensory neurons. J Neurocytol 8:1-18.

Gustafson AL, Eriksson U, Dencker L (1999) CRBP I and CRABP I localisation during olfactory nerve development. Brain Res Dev Brain Res 114:121-126.

Hayward MD, Bocchiaro CM, Morgan JI (2004) Expression of Bcl-2 extends the survival of olfactory receptor neurons in the absence of an olfactory bulb. Brain Res Mol Brain Res 132:221-234.

Johnson BS, Chandraratna RA, Heyman RA, Allegretto EA, Mueller L, Collins SJ (1999) Retinoid X receptor (RXR) agonist-induced activation of dominant-negative RXR-retinoic acid receptor alpha403 heterodimers is developmentally regulated during myeloid differentiation. Mol Cell Biol 19:3372-3382.

Krezel W, Kastner P, Chambon P (1999) Differential expression of retinoid receptors in the adult mouse central nervous system. Neuroscience 89:1291-1300.

LaMantia AS, Bhasin N, Rhodes K, Heemskerk J (2000) Mesenchymal/epithelial induction mediates olfactory pathway formation. Neuron 28:411-425.

Leyssen M, Ayaz D, Hebert SS, Reeve S, De Strooper B, Hassan BA (2005) Amyloid precursor protein promotes post-developmental neurite arborization in the Drosophila brain. EMBO J 24:2944-2955.

Mackay-Sim A (2005) Olfactory ensheathing cells and spinal cord repair. Keio J Med 54:8-14.

Maden M (2001) Role and distribution of retinoic acid during CNS development. Int Rev Cytol 209:1-77.

Mathonnet M, Lalloue F, Petit B, Comte I, Leboutet MJ, Ayer-Le Lievre C (2002) Differential responses of olfactory neurons to axotomy at embryonic and postnatal stages. Neuroscience 109:207-217.

McCaffery P, Wagner E, O’Neil J, Petkovich M, Drager UC (1999) Dorsal and ventral rentinoic territories defined by retinoic acid synthesis, breakdown and nuclear receptor expression. Mech Dev 85:203-214.

McLaughlin B (2004) The kinder side of killer proteases: caspase activation contributes to neuroprotection and CNS remodeling. Apoptosis 9:111-121.

Misner DL, Jacobs S, Shimizu Y, de Urquiza AM, Solomin L, Perlmann T, De Luca LM, Stevens CF, Evans RM (2001) Vitamin A deprivation results in reversible loss of hippocampal long-term synaptic plasticity. Proc Natl Acad Sci USA 98:11714-11719.

Mombaerts P, Wang F, Dulac C, Chao SK, Nemes A, Mendelsohn M, Edmondson J, Axel R (1996) Visualizing an olfactory sensory map. Cell 87:675-686.

Nakatani H, Serizawa S, Nakajima M, Imai T, Sakano H (2003) Developmental elimination of ectopic projection sites for the transgenic OR gene that has lost zone specificity in the olfactory epithelium. Eur J Neurosci 18:2425-2432.

Niederreither K, Fraulob V, Garnier JM, Chambon P, Dolle P (2002) Differential expression of retinoic acid-synthesizing (RALDH) enzymes during fetal development and organ differentiation in the mouse. Mech Dev 110:165-171.

Norlin EM, Alenius M, Gussing F, Hägglund M, Vedin V, Bohm S (2001) Evidence for gradients of gene expression correlating with zonal topography of the olfactory sensory map. Mol Cell Neurosci 18:283-295.

Norlin EM, Vedin V, Bohm S, Berghard A (2005) Odorant-dependent, spatially restricted induction of c-fos in the olfactory epithelium of the mouse. J Neurochem 93:1594-1602.

Pellier-Monnin V, Astic L, Bichet S, Riederer BM, Grenningloh G (2001) Expression of SCG10 and stathmin proteins in the rat olfactory system during development and axonal regeneration. J Comp Neurol 433:239-254.

Plum LA, Parada LF, Tsoulfas P, Clagett-Dame M (2001) Retinoic acid combined with neurotrophin-3 enhances the survival and neurite outgrowth of embryonic sympathetic neurons. Exp Biol Med (Maywood) 226:766-775

Reijntjes S, Blentic A, Gale E, Maden M (2005) The control of morphogen signalling: regulation of the synthesis and catabolism of retinoic acid in the developing embryo. Dev Biol 285:224-237.

Ressler KJ, Sullivan SL, Buck LB (1994) Information coding in the olfactory system: evidence for a stereotyped and highly organized epitope map in the olfactory bulb. Cell 79:1245-1255.

Rossant J, Zirngibl R, Cado D, Shago M, Giguere V (1991) Expression of a retinoic acid response element-hsplacZ transgene defines specific domains of transcriptional activity during mouse embryogenesis. Genes Dev 5:1333-1344.

Schaeren-Wiemers N, Gerfin-Moser A (1993) A single protocol to detect transcripts of various types and expression levels in neural tissue and cultured cells: in situ hybridization using digoxigenin-labelled cRNA probes. Histochemistry 100:431-440.

Schwob JE (2002) Neural regeneration and the peripheral olfactory system. Anat Rec 269:33-49.

Sockanathan S, Perlmann T, Jessell TM (2003) Retinoid receptor signaling in postmitotic motor neurons regulates rostrocaudal positional identity and axonal projection pattern. Neuron 40:97-111.

Strotmann J, Levai O, Fleischer J, Schwarzenbacher K, Breer H (2004) Olfactory receptor proteins in axonal processes of chemosensory neurons. J Neurosci 24:7754-7761.

Sullivan SL, Bohm S, Ressler KJ, Horowitz LF, Buck LB (1995) Targetindependent pattern specification in the olfactory epithelium. Neuron 15:779-789.

Thompson Haskell G, Maynard TM, Shatzmiller RA, Lamantia AS (2002) Retinoic acid signaling at sites of plasticity in the mature central nervous system. J Comp Neurol 452:228-241.

Vassar R, Chao SK, Sitcheran R, Nunez JM, Vosshall LB, Axel R (1994) Topographic organization of sensory projections to the olfactory bulb. Cell 79:981-991.

Verma P, Chierzi S, Codd AM, Campbell DS, Meyer RL, Holt CE, Fawcett JW (2005) Axonal protein synthesis and degradation are necessary for efficient growth cone regeneration. J Neurosci 25:331-342.

Wagner E, Luo T, Drager UC (2002) Retinoic acid synthesis in the postnatal mouse brain marks distinct developmental stages and functional systems. Cereb Cortex 12:1244-1253.

Wallen-Mackenzie A, Mata de Urquiza A, Petersson S, Rodriguez FJ, Friling S, Wagner J, Ordentlich P, Lengqvist J, Heyman RA, Arenas E, Perlmann T (2003) Nurr1-RXR heterodimers mediate RXR ligand-induced signaling in neuronal cells. Genes Dev 17:3036-3047.

Wang TW, Zhang H, Parent JM (2005) Retinoic acid regulates postnatal neurogenesis in the murine subventricular zone-olfactory bulb pathway. Development 132:2721-2732.

Watt WC, Sakano H, Lee ZY, Reusch JE, Trinh K, Storm DR (2004) Odor- 
ant stimulation enhances survival of olfactory sensory neurons via MAPK and CREB. Neuron 41:955-967.

Weiler E, Farbman AI (1997) Proliferation in the rat olfactory epithelium: age-dependent changes. J Neurosci 17:3610-3622.

Weston AD, Blumberg B, Underhill TM (2003) Active repression by unliganded retinoid receptors in development: less is sometimes more. J Cell Biol 161:223-228.

Whitesides J, Hall M, Anchan R, LaMantia AS (1998) Retinoid signaling distinguishes a subpopulation of olfactory receptor neurons in the developing and adult mouse. J Comp Neurol 394:445-461.

Yu CR, Power J, Barnea G, O’Donnell S, Brown HE, Osborne J, Axel R, Gogos JA (2004) Spontaneous neural activity is required for the establishment and maintenance of the olfactory sensory map. Neuron 42:553-566.
Zetterstrom RH, Lindqvist E, Mata de Urquiza A, Tomac A, Eriksson U, Perlmann T, Olson L (1999) Role of retinoids in the CNS: differential expression of retinoid binding proteins and receptors and evidence for presence of retinoic acid. Eur J Neurosci 11:407-416.

Zhang QY (1999) Retinoic acid biosynthetic activity and retinoid receptors in the olfactory mucosa of adult mice. Biochem Biophys Res Commun 256:346-351.

Zhao H, Reed RR (2001) X inactivation of the OCNC1 channel gene reveals a role for activity-dependent competition in the olfactory system. Cell 104:651-660.

Zou DJ, Feinstein P, Rivers AL, Mathews GA, Kim A, Greer CA, Mombaerts P, Firestein S (2004) Postnatal refinement of peripheral olfactory projections. Science 304:1976-1979. 